\title{
TECHNOLOGY OF MAIZE WITH GROWTH STIMULANTS APPLICATION
}

\author{
Malgorzata Szczepanek \\ UTP University of Science and Technology in Bydgoszcz, Poland \\ Malgorzata.Szczepanek@utp.edu.pl
}

\begin{abstract}
One of the ways to reduce the negative impact of site factors on maize growth and yield may be to select appropriate agronomic treatments. The aim of this study was to assess the effect of the different methods of seaweed biostimulant Kelpak and limestone fertilizer Nano Active application on the growth and grain yield of maize. The study was based on a field experiment with maize cultivar Mas 25 A (FAO 250), conducted in three successive growing seasons, in Poland $\left(17^{\circ} 35^{\prime} \mathrm{E} ; 53^{\circ} 09^{\prime} \mathrm{N}\right)$. The experiment was established in the randomized complete block design with four replications on plots with an area of $36 \mathrm{~m}^{2}$. Biostimulant Kelpak is obtained from marine macroalga (Ecklonia maxima) and contains mainly auxins and cytokines. Nano Active is a foliar fertilizer containing $\mathrm{CaO} 40 \%$, as well as $\mathrm{Mg}, \mathrm{Fe}, \mathrm{Mn}, \mathrm{Zn}$. Biostimulant was applied in a dose of $2 \mathrm{l} \cdot \mathrm{ha}^{-1}$ at the 4- or 8-leaf stage, as well as sequentially $1.5 \mathrm{l} \cdot \mathrm{ha}^{-1}$ in each of both those phases. Nano Active was applied in an amount of $2 \mathrm{~kg} \cdot \mathrm{ha}^{-1}$ at 4-leaf stage, alone or with the biostimulant Kelpak applied in a dose of $2 \mathrm{l} \cdot \mathrm{ha}^{-1}$. Response of maize to the time and dose of preparation application depended on the weather conditions. In case of the expected rainfall deficit in the period of intensive stem elongation, the biostimulant had a favourable effect on the grain yield, if it was used before the onset of the stress factor, i.e. at the stage of 4 fully formed leaves. In years with more favourable weather conditions, single application at the 8-leaf stage in a dose of $21 \cdot$ ha $^{-1}$, or sequential, in doses of $1.51 \cdot \mathrm{ha}^{-1}$ at the 4 - and 8-leaf stage, gave better results than in the control. Nano Active increased the maize grain yield as compared with the control only if it was applied together with the seaweed biostimulant.
\end{abstract}

Keywords: Ecklonia maxima, foliar fertilization, maize, roots, seaweed extract, yield.

\section{Introduction}

Maize productivity depends on agronomic and habitat factors. The most important site factors that can cause significant depression of maize yield, if they occur outside of the optimum for the plant, include the temperature and soil humidity. Maize is sensitive to temperature, especially at the initial stage of growth, e.g., up to six fully developed leaves. Even moderately low soil temperatures $<15^{\circ} \mathrm{C}$ are detrimental to root development, fine root branching and root elongation [1]. Moreover, plant availability of sparingly soluble nutrients such as $\mathrm{P}, \mathrm{NH}_{4}{ }^{+}, \mathrm{K}, \mathrm{Fe}, \mathrm{Zn}, \mathrm{Mn}$ and $\mathrm{Cu}$ is particularly affected by low soil temperature [2]. Maize is also highly sensitive to water shortage [3]. Drought during the vegetative phase induces stomatal closure and inhibits photosynthesis, which limit carbohydrate synthesis and cell division [4]. There is no single approach that is sufficient to improve maize performance in drought condition, thus a combination of approaches should be considered [5]. One of the ways to reduce the negative impact of site factors on maize growth and yield may be to select appropriate agronomic treatments. Among them, important role is played by biostimulants, which are used to improve plant growth and impart stress tolerance [6]. Application of compounds stimulating growth and physiological processes may also have a favourable effect on maize productivity [7]. Among the numerous biostimulators, one of the most important groups is marine algae extracts [8]. Many researchers point out that the effect of algae extract applications depends on the dose and timing of the application [9-10]. Based on observations of plants treated with seaweed biostimulants cytokines and cytokinin-like activity is most commonly reported phytohormone effect of seaweed extracts [11]. Foliar fertilizers, especially those with micronutrients, can also have a function similar to biostimulants. The supplementary foliar fertilization during crop growth improves the mineral status of plants, activates a number of physiological processes, and increases the crop yield. The absorption rate of mineral nutrients by aboveground plant parts considerably differs not only among plant species but also among varieties within the same species [12-14].

The aim of the study was to evaluate the effect of the foliar application of the seaweed biostimulant Kelpak and limestone fertilizer Nano Active on the growth of the above-ground and underground parts and the grain yield of maize.

\section{Materials and methods}

The study was based on a one-factor field experiment with the maize cultivar Mas 25 A (FAO $250)$, carried out over 2009-2011 in the Kuyavian-Pomeranian voivodeship $\left(17^{\circ} 35^{\prime} \mathrm{E} ; 53^{\circ} 09^{\prime} \mathrm{N}\right)$, 
Poland, on the Alfisols. The topsoil at the experimental site is characterized by a medium content of available phosphorus 190-210 $\mathrm{mg} \cdot \mathrm{kg}^{-1}$ and potassium $95-150 \mathrm{mg} \cdot \mathrm{kg}^{-1}$ (determined with Egner-Riehm method), very low content of magnesium $<20.0 \mathrm{mg} \cdot \mathrm{kg}^{-1}$ (Schetschabel method ) and slightly acid reaction ( $\mathrm{pH}$ in $1 \mathrm{M} \mathrm{KCL} \mathrm{5.7-6.1)} \mathrm{(with} \mathrm{the} \mathrm{use} \mathrm{of} \mathrm{potentiometry).} \mathrm{The} \mathrm{experiment} \mathrm{was} \mathrm{conducted} \mathrm{in}$ the randomized complete block design with four replications on plots with an area of $36 \mathrm{~m}^{2}$. The preparations Kelpak and/or Nano Active were applied at the initial developmental stages. The preparation Kelpak is obtained from a marine macroalga (Ecklonia maxima Osbeck) belonging to the family of brown algae (Phaeophyta), obtained on the coast of Africa. This product is a pure organic concentrated product extracted from a marine alga (Ecklonia maxima) with the high-pressure technique results in cellular burst, obviating the use of chemicals, heat, freezing or dehydration. This ensures that the compounds are maintained in their active form. Kelpak contains substances responsible for the growth, development and resistance of plants to stress factors, e.g. phytohormones: auxins and cytokines, 11 and $0.031 \mathrm{mg} \cdot \mathrm{l}^{-1}$, respectively, alginians, amino acids, as well as small amounts of macro- and macroelements. Nano Active is a multicomponent foliar fertilizer in the form of powder, containing mostly calcium carbonate and magnesium carbonate, composed of particles with a size of up to $20 \mu \mathrm{m}$, with the declared composition: $\mathrm{CaO} 40 \%, \mathrm{MgO} 4 \%, \mathrm{Fe} 0.168 \%$, $\mathrm{Mn}$ $0.014 \%, \mathrm{Zn} 0.002 \%$ (patent application P.404091). Seaweed biostimulant was applied in a dose of $21 \cdot \mathrm{ha}^{-1}$, at the 4-leaf stage BBCH 14 (the beginning of June) or 8-leaf stage BBCH 18 (the end of June), as well as sequentially, $1.51 \cdot \mathrm{ha}^{-1}$ each, at both these stages. The foliar fertilizer Nano Active was applied in 2010 and 2011, in an amount of $2 \mathrm{~kg} \cdot \mathrm{ha}^{-1}$, at the 4-leaf stage BBCH 14 alone with the biostimulant Kelpak applied in a dose of $21 \cdot \mathrm{ha}^{-1}$. Sowing of maize was performed at the end of April, after the soil reached $8-10^{\circ} \mathrm{C}$. The density of germinating grains was $85000 \cdot \mathrm{ha}^{-1}$, and the row spacing $75 \mathrm{~cm}$. Pre-sowing application of mineral fertilizers included: phosphorus $\left(\mathrm{P}_{2} \mathrm{O}_{5}\right) 70 \mathrm{~kg} \cdot \mathrm{ha}^{-1}$ (triple superphosphate), potassium $\left(\mathrm{K}_{2} \mathrm{O}\right)$ (potassium salt) $80 \mathrm{~kg} \cdot \mathrm{ha}^{-1}$, nitrogen $(\mathrm{N})$ (ammonium nitrate) $51 \mathrm{~kg} \cdot \mathrm{ha}^{-1}$. Additionally, top-dressing with nitrogen (ammonium nitrate) was applied twice: at the beginning of June, at the 7-leaf stage of maize - $50 \mathrm{~kg} \cdot \mathrm{ha}^{-1}-$ and at the end of June, at the 11-leaf stage, additional $50 \mathrm{~kg} \cdot \mathrm{ha}^{-1}$. At the end of May, at the 4-leaf stage of maize, weed control was performed, using the active substances: bromoxynil $144 \mathrm{~g} \cdot \mathrm{ha}^{-1}+$ terbuthylazine $400 \mathrm{~g} \cdot \mathrm{ha}^{-1}+$ rimsulfuron $12.5 \mathrm{~g} \cdot \mathrm{ha}^{-1}$, dissolved in $300 \mathrm{l}$ of water. At the same maize developmental stage, control of Oscinella frit was performed using tiachloprid $50 \mathrm{~g} \cdot \mathrm{ha}^{-1}+$ deltamethrin $5 \mathrm{~g} \cdot \mathrm{ha}^{-1}$. At the end of June, at the stage of 11 maize leaves, treatments against European corn borer were performed using: tiachloprid $50 \mathrm{~g} \cdot \mathrm{ha}^{-1}+$ deltamethrin $5 \mathrm{~g} \cdot \mathrm{ha}^{-1}$. In case of the next appearance of this pest observed at later developmental stages of maize, an additional application was used with lambda-cyhalothrin $5 \mathrm{~g} \cdot \mathrm{ha}^{-1}$. At the beginning of September, at the ripening stage, 5 successive plants were dug out on each plot to assess the root mass. Directly before the harvest, at the beginning of October, on 30 randomly selected plants from the plot, the stem height and the height of setting the main cob were measured, as well as the number of productive cobs (with grain making the functional yield) and nonproductive cobs (with very poorly formed grain, not making the functional yield), and the weight of productive cobs after their husk-shelling. Then after separation of grain from the rachis, the number of grains per cob, grain and rachis weight, thousand grain weight and grain moisture (with the oven-dry method) were determined. The obtained results were subjected to the statistical analysis. The analysis of variance of single experiments in the years was made using the statistical program Analysis of variance for orthogonal experiments by the UTP University of Sciences and Technology in Bydgoszcz. Significance of differences for the results was assessed with Tukey's test, assuming the significance level $p \leq 0.05$.

\section{Results and discussion}

In the area of the field experiments the soil reaches the temperature suitable for sowing maize (8$10{ }^{\circ} \mathrm{C}$ ) at the end of April or at the beginning of May. On average in the long-term period, the highest air temperatures and rainfall totals occur in July (Table 1). In the period of conducting the field experiments, the year 2011, with heavy rainfalls in June and July and higher air temperatures than in the long-term period and in the other years of the study in September, can be regarded as the most favourable to the growth and yield of maize. In spite of low rainfall in August, also 2009 can be regarded as rather favourable to the yield. In contrast, hydrothermal conditions in 2010 were definitely unfavourable to the maize growth and development. In May, in the period of the plant initial growth, 
the temperatures were lower than on average in the long-term period and in the other years of the study. In June, in the stem elongation period, the rainfall deficit caused a noticeable inhibition of growth. Moreover, the relatively low air temperatures at ripening (September) did not favour grain drying.

Table 1

Meteorological data at experimental site in maize growing season

\begin{tabular}{|l|c|c|c|c|c|c|c|c|}
\hline \multirow{2}{*}{ Month } & \multicolumn{4}{|c|}{ Rainfall, mm } & \multicolumn{4}{c|}{ Air temperature, ${ }^{\mathbf{C}}$} \\
\cline { 2 - 10 } & $\mathbf{2 0 0 9}$ & $\mathbf{2 0 1 0}$ & $\mathbf{2 0 1 1}$ & $\begin{array}{c}\mathbf{1 9 4 9 -} \\
\mathbf{2 0 1 1}\end{array}$ & $\mathbf{2 0 0 9}$ & $\mathbf{2 0 1 0}$ & $\mathbf{2 0 1 1}$ & $\begin{array}{c}\mathbf{1 9 4 9 -} \\
\mathbf{2 0 1 1}\end{array}$ \\
\hline May & 85.3 & 92.6 & 38.4 & 43.2 & 12.3 & 11.5 & 13.5 & 12.7 \\
\hline June & 57.4 & 18.1 & 100.8 & 53.7 & 14.5 & 16.7 & 17.7 & 16.3 \\
\hline July & 118.0 & 107.4 & 132.5 & 73.1 & 18.6 & 21.6 & 17.5 & 18.0 \\
\hline August & 17.6 & 150.7 & 67.7 & 53.2 & 18.2 & 18.4 & 17.7 & 17.5 \\
\hline September & 34.4 & 74.7 & 37.0 & 41.4 & 13.7 & 12.2 & 14.3 & 13.2 \\
\hline
\end{tabular}

The maize plants reached a similar height in 2009 and 2011, whereas in 2010, which was unfavourable to maize growth, they were by $19 \%$ lower (Table 2). In the successive years of the study no significant effect of foliar applications using the biostimulant and the fertilizer Nano Active on the plant height was indicated. It was only observed that in 2010 after an early application of the seaweed biostimulant alone or after its application together with the fertilizer Nano Active the plants were slightly higher, by 7.8 i $6.7 \mathrm{~cm}$, respectively, as compared with the control. Similar relationships are presented by Trivedi et al. [15]. In that study the maize was higher (by $8.7 \mathrm{~cm}$ ) after an early (5 leaves) foliar application of a seaweed extract (Kappaphycus alvarezie) as compared with a later (10 leaves). Also a relationship between the stem height of maize and the concentration of the applied seaweed extracts was indicated [10]. In laboratory analyses in greenhouse conditions, soaking seeds in an extract from Ecklonia maxima caused an increase in the stem length and weight, and in the number of leaves of maize seedlings [16-17]. In the present study, the height of setting the main cob was differentiated in the years of the study (Table 2). In 2010, which was the least favourable to the plant growth, the cob was set lower than in 2009 and 2011, by $39 \mathrm{~cm}$ and $16 \mathrm{~cm}$, respectively. The applied preparations had no significant effect on this plant biometric trait.

Table 2

Height of plant and height of cob seating in 2009-2011

\begin{tabular}{|c|c|c|c|c|c|c|}
\hline \multirow{2}{*}{ Treatments } & \multicolumn{3}{|c|}{ Plant height, cm } & \multicolumn{3}{|c|}{ Height of cob seating, $\mathrm{cm}$} \\
\hline & 2009 & 2010 & 2011 & 2009 & 2010 & 2011 \\
\hline Control & 275.5 & 221.8 & 275.2 & 116.5 & 74.7 & 87.8 \\
\hline Kelpak 21 ha $^{-1}$ BBCH 14 & 275.4 & 229.6 & 278.3 & 113.1 & 74.1 & 89.8 \\
\hline $\begin{array}{l}\text { Kelpak } 1.51 \mathrm{ha}^{-1} \text { BBCH } 14 \\
+1.51 \mathrm{ha}^{-1} \mathrm{BBCH} 18\end{array}$ & 280.1 & 225.1 & 276.4 & 114.5 & 77.3 & 89.9 \\
\hline Kelpak 21 ha $^{-1}$ BBCH 18 & 277.2 & 221.8 & 282.6 & 115.4 & 75.2 & 95.2 \\
\hline Nano Active $2 \mathrm{~kg} \mathrm{ha}^{-1}$ BBCH 14 & - & 220.7 & 278.7 & - & 75.9 & 95.0 \\
\hline $\begin{array}{l}\text { Kelpak } 21 \mathrm{ha}^{-1} \\
+ \text { Nano Active } 2 \mathrm{~kg} \mathrm{ha}^{-1} \mathrm{BBCH} 14\end{array}$ & - & 228.5 & 280.6 & - & 75.7 & 89.5 \\
\hline Mean & 277.0 & 224.6 & 278.6 & 114.9 & 75.5 & 91.2 \\
\hline
\end{tabular}

The root mass showed a significant response to the applied preparations (Table 3). In 2009 the roots had a higher mass than in the control after a double (at the 4-leaf and 8-leaf stages) or late (at the 8-leaf stage) application of the seaweed biostimulant. In 2010, which was characterized by rainfall deficit in June, an early application of the biostimulant alone (before the occurrence of the stress factor) or of its mixture with the foliar fertilizer at the same time caused a significant increase in the root mass as compared with the control. In 2011 in each variant of the application of the seaweed biostimulant the root mass was higher than in the control. Earlier laboratory analyses showed that the shaking of maize grain in seaweed solution (Ecklonia maxima) stimulated growth of the root length and mass, an increase in the content of total phenolic, total protein \&-amylase activity in roots [16] as well as nutrient uptake [17]. In a microplot study the effect of foliar applications with the use of an 
extract from algae (Kappaphycus alvarezie) on the root mass depended on the number of applications and the development stage of maize, and it was the highest after four applications [15].

Root weight of five plants in 2009-2011

\begin{tabular}{|c|c|c|c|}
\hline \multirow{2}{*}{ Treatments } & \multicolumn{3}{|c|}{ Root weight (g) } \\
\hline & 2009 & 2010 & 2011 \\
\hline Control & $464.7^{\mathrm{c}}$ & $688.0^{\mathrm{b}}$ & $806.6^{\mathrm{b}}$ \\
\hline Kelpak $21 \cdot$ ha $^{-1}$ BBCH 14 & $508.9^{\mathrm{bc}}$ & $779.3^{\mathrm{a}}$ & $963.7^{\mathrm{a}}$ \\
\hline $\begin{array}{l}\text { Kelpak } 1.51 \cdot \mathrm{ha}^{-1} \text { BBCH } 14 \\
+1.51 \cdot \mathrm{ha}^{-1} \mathrm{BBCH} 18\end{array}$ & $570.0^{\mathrm{ab}}$ & $700.2^{\mathrm{b}}$ & $939.0^{\mathrm{a}}$ \\
\hline Kelpak 2 $1 \cdot$ ha $^{-1}$ BBCH 18 & $604.2^{\mathrm{a}}$ & $684.7^{\mathrm{b}}$ & $910.8^{\mathrm{a}}$ \\
\hline Nano Active $2 \mathrm{~kg} \cdot \mathrm{ha}^{-1} \mathrm{BBCH} 14$ & - & $721.2^{\mathrm{ab}}$ & $885.1^{\mathrm{ab}}$ \\
\hline $\begin{array}{l}\text { Kelpak } 2 \mathrm{l} \cdot \mathrm{ha}^{-1} \\
+ \text { Nano Active } 2 \mathrm{~kg} \cdot \mathrm{ha}^{-1} \mathrm{BBCH} 14\end{array}$ & - & $795.9^{\mathrm{a}}$ & $952.6^{\mathrm{a}}$ \\
\hline Mean & 537.0 & 728.2 & 909.6 \\
\hline
\end{tabular}

Means sharing similar letters in column do not differ significantly at $p \leq 0.05$.

The applied preparations had a significant effect on the number of productive cobs (Table 4). In 2009 a late application of the biostimulant (at the 8-leaf stage) had a favourable effect on this trait in relation to the control. In 2010 an early application (at the 4-leaf stage) with the fertilizer Nano Active, as well as late (at the 8-leaf stage) gave positive effects. In 2011 the number of productive cobs was higher than in the control, if the biostimulant was applied late or twice, or together with the foliar fertilizer. In the successive years of the study no significant effect of the biostimulant or foliar fertilizer on the number of non-productive cobs was observed.

Table 4

Number of productive and unproductive cobs in 2009-2011

\begin{tabular}{|c|c|c|c|c|c|c|}
\hline \multirow{2}{*}{ Treatments } & \multicolumn{3}{|c|}{ No of productive cobs } & \multicolumn{3}{|c|}{ No of unproductive cobs } \\
\hline & 2009 & 2010 & 2011 & 2009 & 2010 & 2011 \\
\hline Control & $8.85^{\mathrm{b}}$ & $7.76^{\mathrm{b}}$ & $9.74^{\mathrm{c}}$ & 5.09 & 5.09 & 3.51 \\
\hline Kelpak $21 \cdot$ ha $^{-1}$ BBCH 14 & $8.92^{\mathrm{b}}$ & $7.98^{\mathrm{ab}}$ & $10.02^{\mathrm{bc}}$ & 4.63 & 4.63 & 3.31 \\
\hline $\begin{array}{l}\text { Kelpak } 1.51 \cdot \mathrm{ha}^{-1} \text { BBCH } 14 \\
+1.51 \cdot \mathrm{ha}^{-1} \mathrm{BBCH} 18\end{array}$ & $9.06^{\mathrm{ab}}$ & $7.95^{\mathrm{ab}}$ & $10.49^{\mathrm{ab}}$ & 5.32 & 5.32 & 3.72 \\
\hline Kelpak $21 \cdot \mathrm{ha}^{-1}$ BBCH 18 & $9.37^{\mathrm{a}}$ & $8.12^{\mathrm{a}}$ & $10.33^{\mathrm{ab}}$ & 4.62 & 4.62 & 3.03 \\
\hline Nano Active $2 \mathrm{~kg} \cdot \mathrm{ha}^{-1} \mathrm{BBCH} 14$ & - & $7.97^{\mathrm{ab}}$ & $10.29^{\text {abc }}$ & - & 2.12 & 4.49 \\
\hline $\begin{array}{l}\text { Kelpak } 2 \mathrm{l} \cdot \mathrm{ha}^{-1} \\
+ \text { Nano Active } 2 \mathrm{~kg} \cdot \mathrm{ha}^{-1} \mathrm{BBCH} 14\end{array}$ & - & $8.11^{\mathrm{a}}$ & $10.68^{\mathrm{a}}$ & - & 3.96 & 3.30 \\
\hline Mean & 9.05 & 7.98 & 10.26 & - & 4.29 & 3.56 \\
\hline
\end{tabular}

Means sharing similar letters in column do not differ significantly at $p \leq 0.05$.

The cob weight was mostly higher after the application of preparations as compared with the control, but the differences were not statistically significant (Table 5). The proportion of the rachis in the cob weight in 2010, characterized by the weather conditions unfavourable to the growth and development of maize, was by about $1 / 3$ higher than in the years that created favourable conditions for the yields. The application of the tested preparations did not have a significant effect on this trait of cobs.

Dry grain yield (with the determined moisture $15 \%$ ) was in 2010 lower as compared with 2009 and 2011 by $40 \%$ and $45 \%$, respectively. One of the reasons for this was the cool weather at the initial period of growth (Table 6). A study by Stone et al. [18] indicates an increase in biomass production and maize grain yield along with an increase in the soil temperature in the period from germination to the $6^{\text {th }}$ leaf formation. Moreover, rainfall deficit during the intensive stem growth had a considerable effect on yield depression. Metanalysis of data from scientific articles published in the years 1980-2015 showed that the yield reduction in maize was $39.3 \%$ at approximately $40 \%$ water reduction [5]. In 2010, which was unfavourable for maize development, an early application of the 
seaweed biostimulant (at the beginning of June, before the drought) or its application together with the foliar fertilizer Nano Active resulted in a significant increase in the grain yield in relation to the control. On treatments with an early application of the preparations also a significant increase in the number of grains per cob was recorded (Table 6). The yield-forming effect of early foliar applications coincided with the root mass increase (Table 3). A relationship between the grain yield and the root weight this year is confirmed by a significant correlation coefficient (Table 8). It is commonly known that the greater the root mass, the better the plant's supply of water and nutrients. A study by Bradocova et al. [2] indicated that seaweed extracts are mainly acting via improved $\mathrm{Zn}$ and $\mathrm{Mn}$ supply to the plant, which are enzymatic co-factors. Also, a favourable effect of the biostimulant on modulation of pathway for the biosynthesis of phytohormones in plant cannot be ruled out [6].

Table 5

Cob weight and proportion of grain in the cob weight in 2009-2011

\begin{tabular}{|c|c|c|c|c|c|c|}
\hline \multirow[t]{2}{*}{ Treatments } & \multicolumn{3}{|c|}{$\begin{array}{c}\text { Cob weight without husk, } \\
\mathrm{kg} \cdot \mathrm{ha}^{-1}\end{array}$} & \multicolumn{3}{|c|}{$\begin{array}{l}\text { Proportion of grain in the } \\
\text { cob weight, } \%\end{array}$} \\
\hline & 2009 & 2010 & 2011 & 2009 & 2010 & 2011 \\
\hline Control & 19.4 & 14.8 & 23.5 & 27.6 & 35.6 & 26.9 \\
\hline Kelpak $21 \cdot \mathrm{ha}^{-1}$ BBCH 14 & 19.4 & 15.4 & 24.0 & 28.0 & 35.7 & 27.0 \\
\hline $\begin{array}{l}\text { Kelpak } 1.5 \mathrm{l} \cdot \mathrm{ha}^{-1} \text { BBCH } 14 \\
+1.5 \mathrm{l} \cdot \mathrm{ha}^{-1} \mathrm{BBCH} 18\end{array}$ & 20.1 & 15.0 & 23.8 & 27.7 & 36.3 & 26.7 \\
\hline Kelpak 2 1. ha ${ }^{-1}$ BBCH 18 & 20.0 & 15.0 & 23.5 & 27.7 & 36.4 & 26.5 \\
\hline Nano Active $2 \mathrm{~kg} \cdot \mathrm{ha}^{-1} \mathrm{BBCH} 14$ & - & 15.1 & 24.2 & - & 36.7 & 26.6 \\
\hline $\begin{array}{l}\text { Kelpak } 2 \mathrm{l} \cdot \mathrm{ha}^{-1} \\
+ \text { Nano Active } 2 \mathrm{~kg} \cdot \mathrm{ha}^{-1} \mathrm{BBCH} 14\end{array}$ & - & 15.1 & 24.6 & - & 35.9 & 26.8 \\
\hline Mean & 19.7 & 15.1 & 23.9 & 27.8 & 36.1 & 26.8 \\
\hline
\end{tabular}

Grain yield and number of seeds per cob of maize in 2009-2011

Table 6

\begin{tabular}{|c|c|c|c|c|c|c|}
\hline \multirow{2}{*}{ Treatments } & \multicolumn{3}{|c|}{ Grain yield, $\mathrm{kg} \cdot \mathrm{ha}^{-1}$} & \multicolumn{3}{|c|}{ No of seeds per cob } \\
\hline & 2009 & 2010 & 2011 & 2009 & 2010 & 2011 \\
\hline Control & $10810^{\mathrm{b}}$ & $6434^{\mathrm{b}}$ & $11738^{\mathrm{b}}$ & $426.5^{\mathrm{b}}$ & $359.6^{\mathrm{b}}$ & $356.0^{\mathrm{c}}$ \\
\hline Kelpak $21 \cdot$ ha $^{-1}$ BBCH 14 & $10891^{\mathrm{b}}$ & $6704^{\mathrm{a}}$ & $12021^{\mathrm{ab}}$ & $425.4^{\mathrm{b}}$ & $377.6^{\mathrm{a}}$ & $361.6^{\mathrm{bc}}$ \\
\hline $\begin{array}{l}\text { Kelpak } 1.51 \cdot \mathrm{ha}^{-1} \text { BBCH } 14 \\
+1.51 \cdot \mathrm{ha}^{-1} \mathrm{BBCH} 18\end{array}$ & $11382^{\mathrm{a}}$ & $6432^{b}$ & $12018^{\mathrm{ab}}$ & $444.0^{\mathrm{ab}}$ & $370.9^{\mathrm{ab}}$ & $380.0^{\mathrm{a}}$ \\
\hline Kelpak $21 \cdot$ ha $^{-1}$ BBCH 18 & $11139^{\mathrm{ab}}$ & $6493^{b}$ & $12213^{\mathrm{a}}$ & $468.6^{\mathrm{a}}$ & $367.6^{\mathrm{ab}}$ & $370.2^{\mathrm{ab}}$ \\
\hline Nano Active $2 \mathrm{~kg} \cdot \mathrm{ha}^{-1} \mathrm{BBCH} 14$ & - & $6429^{\mathrm{b}}$ & $12062^{\mathrm{ab}}$ & - & $364.9^{\mathrm{ab}}$ & $359.4^{\mathrm{bc}}$ \\
\hline $\begin{array}{l}\text { Kelpak } 2 \mathrm{l} \cdot \mathrm{ha}^{-1} \\
+ \text { Nano Active } 2 \mathrm{~kg} \cdot \mathrm{ha}^{-1} \mathrm{BBCH} 14\end{array}$ & - & $6720^{\mathrm{a}}$ & $12295^{\mathrm{a}}$ & - & $378.6^{\mathrm{a}}$ & $370.5^{\mathrm{ab}}$ \\
\hline Mean & 11056 & 6535 & 12058 & 441.1 & 369.9 & 366.3 \\
\hline
\end{tabular}

Means sharing similar letters in column do not differ significantly at $p \leq 0.05$.

In 2011, the year which was most favourable to maize growth, the highest increase in the grain yield in relation to the control was caused by an application of the biostimulant with the foliar fertilizer at the 4-leaf stage (Table 6). Moreover, also grain yields after the later application of the biostimulant alone were higher than in the control. This effect may be partly attributed to an increasing number of productive cobs (Table 4) and a number of grains per cob (Table 6). In 2009 a significant increase in yield as compared with the control was caused by two applications of a biostimulant, $1.5 \mathrm{l} \cdot \mathrm{ha}^{-1}$ each, at the 4-leaf and 8-leaf stages. Also a tendency to increase the number of grains per cob and the thousand grain weight was noted on this treatment, but the differences of these traits in relation to the control were not statistically proved. Similarly in a study by [15], the yield components like the number of grains per cob and 1000 grain weight were higher after several applications of an extract from algae (Kappaphycus alvarezii) as compared with the control. The results of laboratory analyses presented in the literature indicate a favourable effect of the seed application of seaweed biostimulants on germination and seedling vigour [19-20]. 
A favourable effect of a biostimulant from algae (Kappaphycus alvarezii and Gracilaria edulis) in maize field cultivation was shown in a study in the north-east hill region of India, where seaweed saps significantly improved the grain yield by 10.5-13.1\% [9]. In another study [19], the yield components of maize like the length of cobs, grain rows/cob and grain yield were significantly higher with foliar application of seaweed extract either 3 or 2 times. A favourable effect of the seaweed extract on the cob length, the number of grain per plant, and grain yield per plant was shown in pot experiments [21].

In respect of composition and fragmentation, the limestone foliar fertilizer Nano Active is very similar to the fertilizer Lithovit, the action of which has been the subject of scientific research. Lithovit jest produced by milling natural limestone in special mills down to particle diameter $<10 \mu$ can easily be adsorbed directly through the stomata of plant leaves [22-23]. The literature reports indicate the favourable effect of this fertilizer on plant condition. It significantly increased the total chlorophyll, total carotenoids, total soluble sugar and proline concentrations under stress conditions compared to control wheat plants [24]. A similar response was noted in cotton plants [23]. In a study of broccoli, Lithovit enhanced the plant height, main head weight and the total head yield [22]. Although, Lithovit acts as a fertilizer, the mechanism of its action is still not completely clear. Most likely, it is due to supplying the plants with carbon dioxide $\left(\mathrm{CO}_{2}\right)$ in much higher concentration than that in the atmosphere and so enabling the photosynthesis to take place with higher degree leading to a stronger natural growth and, consequently, increased yield. Furthermore, the supplements of micro-nutrients increase the enzymatic activity that plays a role in this process [22].

Table 7

Thousand grain weight and grain moisture at harvest in 2009-2011

\begin{tabular}{|c|c|c|c|c|c|c|}
\hline \multirow{2}{*}{ Treatments } & \multicolumn{3}{|c|}{ 1000-grain weight, $g$} & \multicolumn{3}{|c|}{ Grain moisture, \% } \\
\hline & 2009 & 2010 & 2011 & 2009 & 2010 & 2011 \\
\hline Control & 341.7 & 275.1 & 396.3 & 35.4 & 41.9 & 29.6 \\
\hline Kelpak $21 \cdot$ ha $^{-1}$ BBCH 14 & 345.7 & 285.4 & 395.7 & 33.6 & 41.6 & 29.2 \\
\hline $\begin{array}{l}\text { Kelpak } 1.51 \cdot \mathrm{ha}^{-1} \text { BBCH } 14 \\
+1.51 \cdot \mathrm{ha}^{-1} \mathrm{BBCH}^{18}\end{array}$ & 359.3 & 273.3 & 397.7 & 33.4 & 42.5 & 30.0 \\
\hline Kelpak $21 \cdot$ ha $^{-1}$ BBCH 18 & 344.9 & 278.0 & 394.1 & 34.7 & 41.1 & 29.0 \\
\hline Nano Active $2 \mathrm{~kg} \cdot \mathrm{ha}^{-1} \mathrm{BBCH} 14$ & - & 274.2 & 390.4 & - & 42.4 & 30.1 \\
\hline $\begin{array}{l}\text { Kelpak } 2 \mathrm{l} \cdot \mathrm{ha}^{-1} \\
+ \text { Nano Active } 2 \mathrm{~kg} \cdot \mathrm{ha}^{-1} \mathrm{BBCH} 14\end{array}$ & - & 287.0 & 392.2 & - & 41.0 & 29.8 \\
\hline Mean & 347.9 & 278.8 & 394.4 & 34.3 & 41.8 & 29.6 \\
\hline
\end{tabular}

Table 8

Relationship of grain yield and biometric features - Pearson correlation coefficients

\begin{tabular}{|l|c|c|c|}
\hline \multirow{2}{*}{ Characteristics } & \multicolumn{3}{|c|}{ Year } \\
\cline { 2 - 4 } & $\mathbf{2 0 0 9}$ & $\mathbf{2 0 1 0}$ & $\mathbf{2 0 1 1}$ \\
\hline Plant height & $0.97^{*}$ & $0.89^{*}$ & $0.88^{*}$ \\
\hline Height of cob seating & -0.18 & -0.44 & 0.48 \\
\hline Root weight & 0.80 & $0.92^{*}$ & 0.72 \\
\hline No of productive cobs & 0.58 & 0.48 & $0.86^{*}$ \\
\hline No of unproductive cobs & -0.05 & 0.03 & -0.25 \\
\hline Cob weight without husk & 0.93 & 0.65 & 0.59 \\
\hline Proportion of grain in the cob weight & -0.26 & -0.45 & -0.40 \\
\hline No of seeds per cob & 0.60 & $0.87^{*}$ & 0.52 \\
\hline 1000-grain weight & 0.89 & $0.99^{*}$ & -0.52 \\
\hline Grain moisture & -0.57 & -0.68 & -0.08 \\
\hline
\end{tabular}

*significant at $p \leq 0.05$

The literature reports indicate a significant relationship between the thousand seed weight of maize and the concentration of applied seaweed extracts [10]. In the present study, foliar applications using the biostimulant Kelpak and the foliar fertilizer Nano Active did not have a significant effect on the thousand grain weight or grain moisture during the harvest (Table 7). These traits, however, were 
highly differentiated in the years of the study. The grain was the most plump (the highest thousand grain weight) and the driest in 2011. Unfavourable conditions during the maize growth in 2010 caused a reduction in the thousand grain weight in comparison to 2009 and 2011 by nearly $20 \%$ and $30 \%$, respectively. In 2010 the poorly formed grain was also characterized by the highest moisture during harvest.

\section{Conclusions}

1. Based on the results it can be stated that the response of maize grown for grain in the KuyavianPomeranian region in Poland to the doses and application times of biostymulant Kelpak (Ecklonia maxima) and the limestone foliar fertilizer Nano Active was dependent on the pluvio-thermal conditions in the years of the study.

2. In the years favourable to the maize growth, a single application of the algae extract $\left(2 \mathrm{l} \cdot \mathrm{ha}^{-1}\right.$, $\mathrm{BBCH}$ 14) caused an increase in the maize grain yield up to $475 \mathrm{~kg} \cdot \mathrm{ha}^{-1}$ and two applications $\left(1.51 \cdot \mathrm{ha}^{-1}, \mathrm{BBCH} 14+1.51 \cdot \mathrm{ha}^{-1}, \mathrm{BBCH} 18\right)$ up to $572 \mathrm{~kg} \cdot \mathrm{ha}^{-1}$.

3. In case of an expected rainfall deficit during the intensive stem elongation an early application of the biostimulant before the occurrence of the stress factor (at the stage of 4 fully formed leaves) gave better results.

4. In the years with an average course of weather, a later application, at the 8-leaf stage, in a dose of $2 \mathrm{l} \cdot \mathrm{ha}^{-1}$, or sequentially, $1.5 \mathrm{l} \cdot \mathrm{ha}^{-1}$ each at both mentioned stages, gave better results than in the control.

5. The limestone foliar fertilizer Nano Active increased the maize grain yield as compared with the control only if it was applied together with the biostimulant Kelpak.

\section{References}

[1] Cutforth H.W., Shaykewich C.F., Cho C.M. Effect of soil water and temperature on corn (Zea mays L.) root growth during emergence. Canadian Journal of Soil Science, vol. 66, 1986, pp. 51-58.

[2] Bradáčová K., Weber N.F., Morad-Talab N. etc. Micronutrients ( $\mathrm{Zn} / \mathrm{Mn})$, seaweed extracts, and plant growth-promoting bacteria as cold-stress protectants in maize. Chemical and Biological Technologies in Agriculture, vol. 3, 2016, 10 p.

[3] Chaichi M.R., Keshavarz-Afshar R., Saberi M. etc. Alleviation of salinity and drought stress in corn production using a non-ionic surfactant. Journal Animal and Plant Science, vol. 26, 2016, pp. 1042-1047.

[4] Barnábas B., Jäger K., Fehér A. The effect of drought and heat stress on reproductive processes in cereals. Plant Cell Environment, vol. 31, 2008, pp. 11-38.

[5] Daryanto S., Wang L., Jacinthe P.-A. Global synthesis of drought effects on maize and wheat production. PloS ONE, vol. 11, 2016, 15 p.

[6] Wally O.S.D., Critchley A.T., Hiltz D. etc. Regulation of phytohormone biosynthesis and accumulation in arabidopsis following treatment with commercial extract from the marine macroalga Ascophyllum nodosum Journal of Plant Growth Regulation, vol. 32: 2013, pp. 324-339.

[7] Szczepanek M. Wilczewski E. Maize response to soil-applied humic substances and foliar fertilization with potassium. Journal of Animal and Plant Science, vol. 26, 2016, pp. 1298-1303.

[8] Van Oosten M.J., Pepe O., De Pascale S., etc. The role of biostimulants and bioeffectors as alleviators of abiotic stress in crop plants Chemical and Biological Technologies in Agriculture, vol. 4, 2017, 5 p.

[9] Layek J., Das A., Ramkrushna G.I. etc. Seaweed sap: a sustainable way to improve productivity of maize in North-East India. International Journal of Environmental Studies, vol. 72, 2015, pp. 305-315.

[10] Singh S., Singh M.K., Pal S.K., etc. Sustainable enhancement in yield and quality of rain-fed maize through Gracilaria edulis and Kappaphycus alvarezii seaweed sap Journal of Applied Phycology, vol. 28: 2016, pp .2099-2112.

[11] Stirk W.A., Novak O., Strnad M. etc. Cytokinins in macroalgae. Plant Growth Regulation. vol. 41: 2003, pp. 13-24. 
[12]Liu H., Gan W., Z., Zhao P. Effects of zinc fertilizer rate and application method on photosynthetic characteristics and grain yield of summer maize. Journal of Soil Science and Plant Nutrition, vol. 16, 2016, pp. 550-562.

[13] Jezek M., Geilfus C.-M., Bayer A. etc. Photosynthetic capacity, nutrient status, and growth of maize (Zea mays L.) upon $\mathrm{MgSO}_{4}$ leaf-application. Frontiers in Plant Science, vol. 5, 2015, 10p.

[14] Andrić L., Kovačević V., Kadar I. etc. Genotypic effects on boron concentrations and response on boron fertilization in maize inbred lines. Genetika, vol. 48, 2016, pp. 297-305.

[15] Trivedi K., K.G. Anand, D. Kubavat, R. Kumar, P. Vaghela and A. Ghosh (2017). Crop stage selection is vital to elicit optimal response of maize to seaweed bio-stimulant application. Journal of Applied Phycology, vol. 29, 2017, pp. 2135-2144.

[16] Rengasamy K.R.R., Kulkarni M.G., Stirk W.A. etc. Eckol improves growth, enzyme activities, and secondary metabolite content in maize (Zea mays cv. Border King) Journal of Plant Growth Regulation, vol. 34, 2015, pp. 410-416.

[17] Omar H., Abdullatif B., Al-Kazan M. etc. Various applications of seaweed improves growth and biochemical constituents of Zea mays L. and Helianthus annuus L. Journal of Plant Nutrition, vol. 38, 2015, pp. 8-40.

[18] Stone P.J., Sorensen I.B., Jamieson P.D. Effect of soil temperature on phenology, canopy development, biomass and yield of maize in a cool-temperate climate. Field Crops Research, vol. 63: 1999, pp. 169-178.

[19]Layek J., Das A., Ramkrushna G.I. etc. Effect of seaweed sap on germination, growth and productivity of maize (Zea mays) in North Eastern Himalayas. Indian Journal of Agronomy, vol. 61, 2016, pp. 354-359.

[20] Paungfoo-Lonhienne C., Lonhienne T.G.A., Andreev A., Effects of humate supplemented with red seaweed (Ahnfeltia tobuchiensis) on germination and seedling vigour of maize. Australian Jourbnal of Crop Science, vol. 11, 2017, pp. 690-693.

[21] Mondal D., Ghosh A., Prasad K. etc. Elimination of gibberellin from Kappaphycus alvarezii seaweed sap foliar spray enhances corn stover production without compromising the grain yield advantage. Plant Growth Regulation, vol. 75: 2015, pp. 657-666.

[22] Nassef D.M.T., Nabeel A.H.M. Response of two broccoli cultivars to foliar application of Lithovit fertilizer under two planting methods. Assiut Journal Agricultural Science, vol. 43, 2012, pp. 27-45.

[23] Shallan M.A., Hassan H.M.M., Namich A.A.M. etc. The influence of Lithovit fertilizer on the chemical constituents and yield characteristics of cotton plant under drought stress. International Journal of ChemTech Research, vol. 9, 2016, pp. 1-11.

[24] Maswada H.F., Abd El-Rahman L.A. Inducing salinity tolerance in wheat plants by hydrogen peroxide and Lithovit "a nano- $\mathrm{CaCO}_{3}$ fertilizer. Journal of Agriculture Research Kafr El-Sheikh University, vol. 40, 2014, pp. 696-719. 